\title{
Co-expression of NGF and Its High-affinity Receptor TrkA in the Rat Carotid Body Chief Cells
}

\author{
Miyuki Yamamoto ${ }^{1}$ and Shoichi Iseki ${ }^{1}$ \\ ${ }^{\prime}$ Department of Histology and Embryology, Graduate School of Medical Science, Kanazawa University, Kanazawa 920-8640, Japan
}

Received May 16, 2003; accepted June 25, 2003

\begin{abstract}
The expression and localization of NGF and its high-affinity receptor, TrkA, in the rat carotid body was investigated by use of in situ hybridization and immunohistochemistry, respectively. The immunoreactivity for TrkA was detected in most of chief cells and sustentacular cells, as well as in some nerve axons and perineurial cells, but not in Schwann cells. In electron microscopy, the immu-
\end{abstract}

noreactivity was localized to the cytoplasm. The mRNA for NGF was localized to most of chief cells and possibly also to sustentacular cells. These results demonstrated that carotid body chief cells, having the neural crest origin, produce both NGF and TrkA, implying a paracrine-autocrine role of NGF in the carotid body.

Key words: NGF, TrkA, carotid body, in situ hybridization, immunohistochemistry

\section{Introduction}

Nerve growth factor (NGF) is a member of the small family of target-derived neurotrophic factors, which also includes brain-derived neurotrophic factor (BDNF), neurotrophin-3 (NT-3), and neurotrophin-4 (NT-4) [8, 16]. NGF has essential functions in survival, differentiation and synaptic plasticity of neural crest-derived sensory and sympathetic neurons as well as certain cholinergic neurons of the basal forebrain nuclei [33]. The biological effects of NGF are mediated through the ligand-specific high-affinity tyrosine kinase receptor TrkA and the common low-affinity receptor p75NTR. TrkA activates a series of protein phosphorylation cascades that results in the trophic effects of NGF $[19,33]$. In contrast, p75NTR is known to enhance TrkA phosphorylation in a variety of cells by increasing the ability of TrkA to bind NGF [5].

The carotid body is an arterial chemoreceptor organ that senses the pressures of $\mathrm{O}_{2}$ and $\mathrm{CO}_{2}$ as well as blood $\mathrm{pH}$, and regulates the cardiopulmonary functions by reflex via primary afferent fibers of the carotid sinus nerve derived from the petrosal ganglion of the glossopharyngeal nerve [11]. The carotid body contains aggregates of chief cells, sustentacular cells, nerve fibers, and nerve terminals. The parenchymal chief cells are generally thought to function as primary chemosensory transducers that depolarize the affer-

Correspondence to: Shoichi Iseki, M.D., Ph.D., Department of Histology and Embryology, Graduate School of Medical Science, Kanazawa University, Kanazawa 920-8640, Japan. ent nerve endings by releasing excitatory neurotransmitters [13], and the sustentacular cells as glia-like supporting cells [20]. The mammalian carotid body also receives efferent innervation both from the superior cervical sympathetic ganglion (via the ganglio-glomerular nerve) and from the carotid sinus nerve/glossopharyngeal nerve [28]. It has been demonstrated that the efferent mechanisms can modulate the sensitivity of this chemoreceptor organ to hypoxia, hypercapnia, and acidosis [24, 28].

The chief cells and the sustentacular cells of the mammalian carotid body originate in the neural crest and resemble chromaffin cells of the sympathoadrenal lineage [30]. Several immature members of this lineage are known to respond to peptide growth factors, particularly nerve growth factor (NGF) and basic fibroblast growth factor (bFGF), by undergoing mitosis and/or neuronal differentiation $[3,10,29,31,35,43]$. Though NGF has been implicated in the fetal and early postnatal development of carotid body chief cells in vivo [1], several studies in vitro have failed to demonstrate NGF-responsiveness of these cells in the perinatal period $[12,17,27,34]$. These studies raised questions about the relationship of chief cells to more established members of the sympathoadrenal lineage.

To clarify the characteristics of the sympathoadrenal lineage of carotid body, we examined the localization of TrkA immunoreactivity in the adult rat carotid body. To ascertain what cell types display TrkA immunoreactivity, immuno-electronmicroscopy was also performed. Furthermore, the expression and localization of NGF mRNA in the carotid body was examined using in situ hybridization. 


\section{Materials and Methods}

\section{Animals and tissue preparation}

Male Wistar rats weighing 150-200 gm were fixed under pentobarbital anesthesia by transcardiac perfusion with cold physiological saline followed by $4 \%$ paraformaldehyde in $0.1 \mathrm{M}$ phosphate buffer, $\mathrm{pH}$ 7.4. Carotid bifurcations were excised out and immersed in the same fixative for further 4 $\mathrm{hr}$. The tissue blocks, after rinsing overnight with the phosphate buffer containing 30\% sucrose for cryoprotection, were frozen and cut into $12 \mu \mathrm{m}$ sections with a cryostat.

\section{Immunohistochemistry}

For light microscopic immunohistochemistry, the cryostat sections were mounted on glass slides and treated successively with $0.3 \%$ Tween 20 in PBS for $1 \mathrm{hr}$, with $0.3 \%$ hydrogen peroxide in methanol for $10 \mathrm{~min}$, and with $5 \%$ normal swine serum (Dakopatts, Glostrup, Denmark) for 30 $\min$. They were then incubated with a rabbit anti-TrkA antibody (Santa Cruz Biotechnology, Inc., Santa Cruz, CA) at $1 \mu \mathrm{g} / \mathrm{ml}$ overnight at room temperature. The specificity of this antibody was characterized in a previous study [37]. After washing with PBS, the immunoreaction sites were made visible by incubating the sections successively at room temperature with a biotinylated anti-rabbit IgG antibody (Vector Laboratories, Inc., Burlingame, CA) diluted at 1:200 in PBS for $1 \mathrm{hr}$, streptavidin-conjugated horseradish peroxidase (Dakopatts) diluted at 1:500 in PBS for $1 \mathrm{hr}$, and finally with a mixture of $0.01 \% 3$ '-diaminobenzidine tetrahydrochloride and $0.02 \%$ hydrogen peroxide in $50 \mathrm{mM}$ Tris-HCl buffer, $\mathrm{pH} 7.6$ [2].

For electron microscopic immunohistochemistry by pre-embedding method, the immunostained cryosections were postfixed with $0.5 \% \mathrm{OsO}_{4}$ for $20 \mathrm{~min}$, stained with $0.5 \%$ uranium acetate for $30 \mathrm{~min}$, dehydrated with a graded ethanol series, and were embedded in an epoxy resin (Selva Feinbiochemica GmbH \& Co., Heidelberg, Germany). Ultrathin sections were made and examined with an electron microscope (Hitachi H-700) at $100 \mathrm{kV}$.

\section{In situ hybridization}

A 48-base oligonucleotide probe complementary to rat NGF mRNA (nucleotide 374-421) [40] was synthesized (Japan Bio Service; Asaka, Japan) and used as the antisense probe. The sense probe for the same portion was also synthesized. Both probes were labeled at the 3 ' end with [ $\alpha$-thio$\left.{ }^{35} \mathrm{~S}\right]$-dATP (46.3 Tbq/mmol; DuPont; Wilmington, DE) using terminal transferase (BRL, Gaithersburg, MD) to the specific activities of $2-3 \times 10^{8} \mathrm{dpm} / \mu \mathrm{g}$. Hybridization of the tissue sections with the oligonucleotide probes was performed essentially as described previously [38]. The cryosections on glass slides were refixed with $4 \%$ paraformaldehyde in phosphate buffer for $10 \mathrm{~min}$, washed with PBS containing $2 \mathrm{mg} / \mathrm{ml}$ glycine, acetylated with $0.25 \%$ acetic anhydride/0.1 M triethanolamine ( $\mathrm{pH} 8.0$ ), and were pre-hybridized at room temperature for $2 \mathrm{hr}$. The (pre)hybridization solution was composed of $50 \%$ deionized formamide,
4×SSC, $0.1 \mathrm{M}$ phosphate buffer $(\mathrm{pH} 7.2), 1 \times$ Denhardt's solution, 2\% Sarkosyl, $2 \mathrm{mM}$ 2-mercaptoethanol, and 250 $\mu \mathrm{g} / \mathrm{ml}$ denatured salmon sperm DNA. After rinsing with $2 \times \mathrm{SSC}$ and dehydration through a graded ethanol series, the sections were hybridized with the ${ }^{35} \mathrm{~S}$-labeled probes present at $5 \times 10^{5} \mathrm{cpm}$ in $50 \mu \mathrm{l}$ of (pre)hybridization solution for each slide. After incubation for $19 \mathrm{hr}$ at $37^{\circ} \mathrm{C}$, the slides were washed with three changes of $1 \times \mathrm{SSC}$ plus $0.1 \%$ Sarkosyl for a total time of $2 \mathrm{hr}$ at $37^{\circ} \mathrm{C}$ and dehydrated through a graded ethanol series containing $0.3 \mathrm{M}$ ammonium acetate. The air-dried slides were dipped in Kodak NTB-2 emulsion and exposed for up to 8 weeks at $4{ }^{\circ} \mathrm{C}$. They were then developed in Kodak D19, stained with hematoxylin and eosin, and examined with an Olympus BH-2 microscope under bright- and dark-field conditions.

\section{Results}

\section{Immunoreactivity for TrkA}

In light microscopy, the carotid body was composed of scattered cell groups interspersed with nerve fibers. Each cell group contained chief cells and sustentacular cells, both of which appeared to be immunopositive for TrkA (Fig. 1a, b). The chief-cell immunoreactivity was moderate to strong in intensity and present diffusely in the cytoplasm, whereas the sustenticular cell immunoreactivity was strong and localized primarily to the cytoplasmic processes. Around the cell groups and around capillaries, thin fibers and small dots with moderate immunoreactivity were recognized. No immunoreactivity was detected in the carotid body when the primary antibody was replaced with preimmune rabbit serum (Fig. 1c).

In immunoelectron microscopy of the cell groups, chief cells were identified with their small cytoplasmic granules, $100-250 \mathrm{~nm}$ in diameter, with round to oval core of homogeneously high electron density (Fig. 2a). The immunoreactive material in chief cells appeared to be localized diffusely in the cytoplasm. In sustentacular cells, the immunoreactivity was stronger than in chief cells and was localized preferentially in the cytoplasmic processes. No immunoreactivity was present in the mitochondria or nucleus of chief cells or sustentacular cells. The fibrous and dot-like immunoreactivity observed with light microscopy were revealed to belong to nerve fiber bundles, in which many but not all unmyelinated axons were immunopositive in the axoplasm and were enclosed by immunonegative Schwann cells (Fig. 2b). Furthermore, the bundles were invested by perineurium composed of a few layers of perineurial cells, many of which were also immunopositive. Perineurial cells were identified with their oblong nucleus, scanty perikaryal cytoplasm, thin cytoplasmic processes and many pinocytotic vesicles. The immunoreactive material appeared to be localized diffusely in the cytoplasm of perineurial cells.

\section{Expression of NGF mRNA}

In in situ hybridization, autoradiographic silver grains representing the hybridization signal for NGF mRNA were 

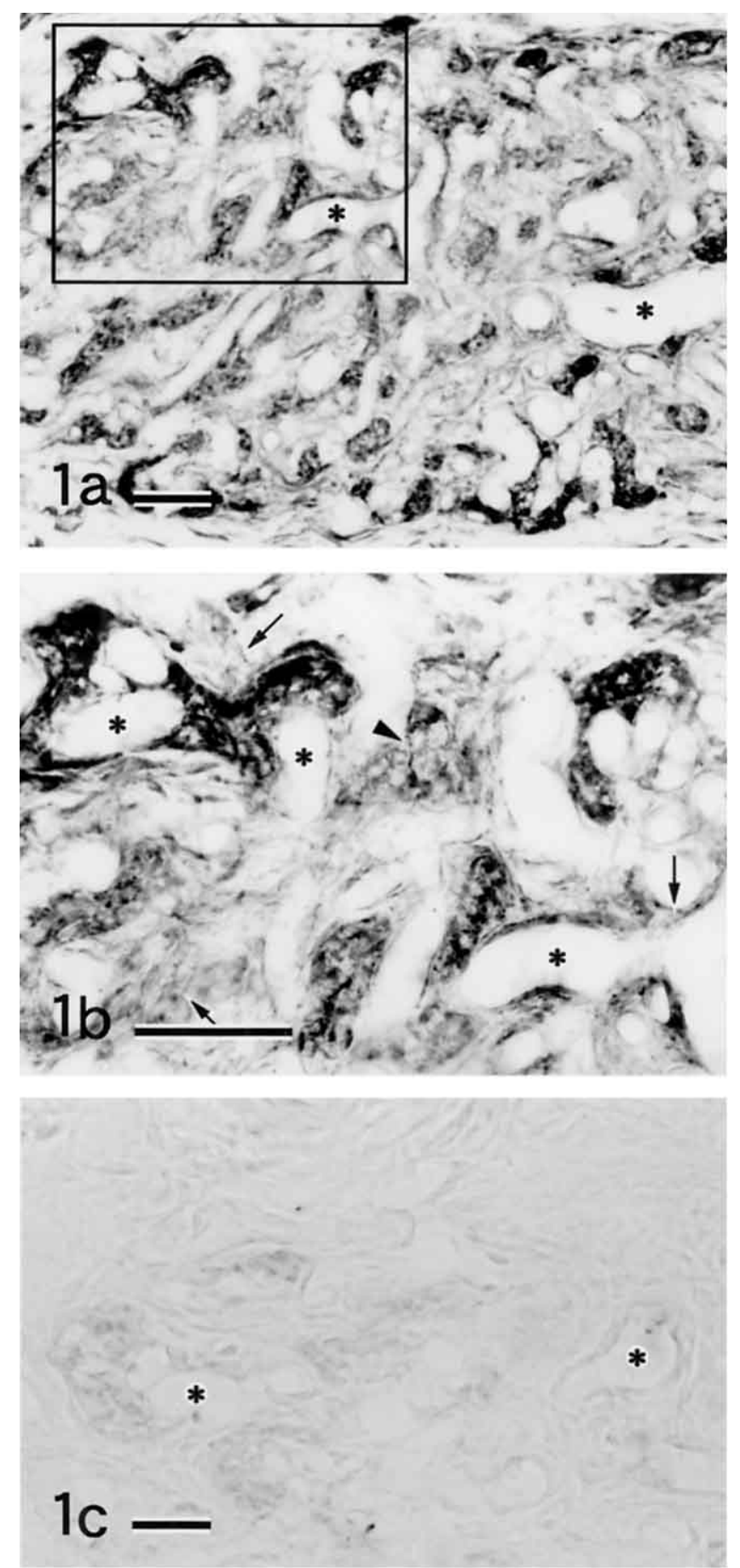

Fig. 1. Light micrographs showing immunohistochemistry of rat carotid body with anti-TrkA antibody $(\mathbf{a}, \mathbf{b})$ and preimmune rabbit $\operatorname{IgG}(\mathbf{c})$. (b) is a magnification of the inset in $(\mathbf{a}) .(\mathbf{a}, \mathbf{b})$ Scattered cell groups composed of chief cells and sustentacular cells are immunostained. A sustentacular cell shows an intensely immunoreactive cytoplasmic process (arrow head) within a cell group. Arrows show fiber- or dot-like immunoreactivity due to nerve fibers. (c) No immunostaining is observed in the section incubated with preimmune rabbit IgG. asterisks, capillary. Bars $=50 \mu \mathrm{m}$. detected abundantly in the carotid body (Fig. 3a, c). Discrete clusters of silver grains corresponding to the cell groups consisting of chief and sustentacular cells were clearly discerned (Fig. 3d). The localization of grains in the cytoplasm of most chief cells was apparent. However, it was difficult to determine if sustentacular cells were also positive in signal, because of the poor spatial resolution of grain localization and the difficulty in distinguishing the thin cytoplasm areas of sustentacular cells in the autoradiograms. The absence of any specific signal in the carotid body hybridized with the sense probe verified the specificity of the positive mRNA signal (Fig. 3b).

\section{Discussion}

To our knowledge, the present study reports for the first time the distribution of TrkA immunoreactivity and NGF mRNA in the carotid body of normal adult rats. Vega et al. [37] previously reported the occurrence of TrkA immunoreactivity in perineurial cells, endoneurial fibroblasts, Schwann cells and large axons of the nerve truncus supplying human digital skin. In the present study, using the same commercial antibody as that used by the previous authors, we have demonstrated the presence of TrkA immunoreactivity in perineurial cells and axons of the carotid body. In addition, the present results have revealed that TrkA immunoreactivity also occurs in carotid body chief cells and sustentacular cells. In our previous studies, occurrence of the immunoreactivity for the p75NTR low-affinity NGF receptor was demonstrated in chief cells and sustentacular cells of the carotid body, as well as in the terminal perineurial cells of peripheral nerves in normal adult rats [21, 42]. The antiTrkA antiserum used in the present study was raised against aminoacids 754-790 at the C terminus of rat TrkA and thus considered to recognize the intracellular catalytic domain of the high-affinity NGF receptor present in the membrane [23]. The diffuse distribution of TrkA immunoreactivity in the cytoplasm of chief cells and sustentacular cells may reflect the internalization of TrkA after binding with its ligand, NGF, as suggested by Bhattacharya et al. [7]. Taken together, these results establish that carotid body chief cells and sustentacular cells, expressing both the low- and high-affinity NGF receptors, are the target of NGF. Chief cells and sustentacular cells of the carotid body are derived from the neural crest and belong to the sympathoadrenal lineage [30]. However, it has not been clear if the cells in the carotid body are NGF-dependent as are other members of sympathoadrenal lineage including the neurons of the sympathetic ganglia [22] and the chromaffin cells of the adrenal medulla [26]. In this respect, the present results seem to reinforce the sympathoadrenal characteristic of carotid body chief cells and sustentacular cells.

The present results also provide in situ hybridization evidence that at least chief cells and possibly both chief cells and sustentacular cells of the carotid body express NGF mRNA. In the adult mouse, the duct cell of submandibular gland is the largest source of NGF, although the physiol- 

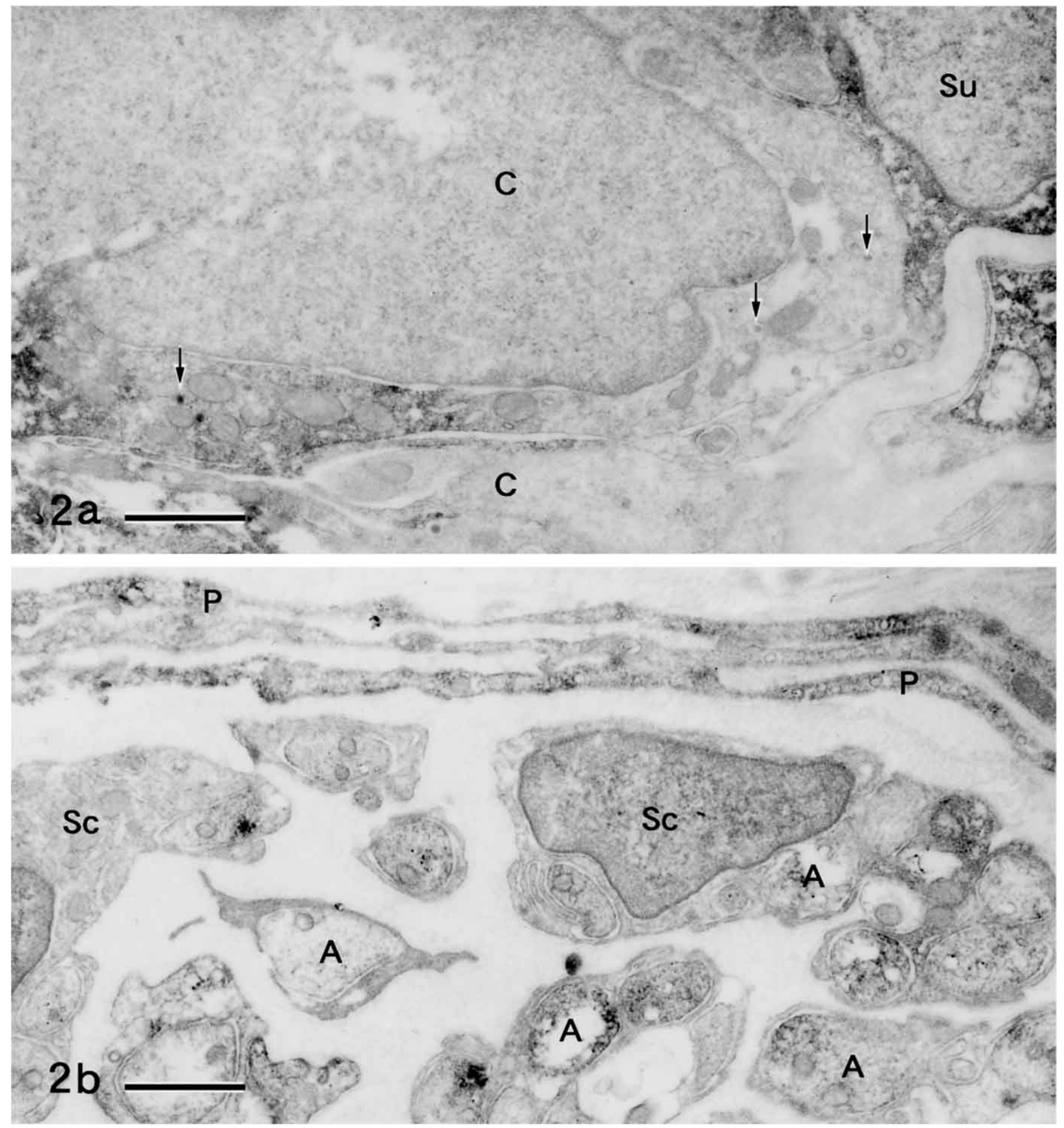

Fig. 2. Electron micrographs showing immunohistochemistry for TrkA in a cell group (a) and of a nerve bundle (b) in the carotid body. The reaction products are localized to the cytoplasm of chief cells $(\mathrm{C})$, sustentacular cells ( $\mathrm{Su}$ ), perineurial cells (P) and nerve axons (A), but not to the cytoplasm of Schwann cells (Sc). The chief cells are recognized by their cytoplasmic-cored vesicles (arrows). Bars=1 $\mu \mathrm{m}$.

ogical meaning of this phenomenon is still obscure [22]. In other animal species, including the rat, the submandibular gland produces no significant levels of NGF. Instead, NGF is mainly produced by the target nonneural cells, including the keratinocytes, fibroblasts and muscle cells, in the peripheral tissues densely innervated by sensory and sympathetic nerves $[6,22,32]$. NGF in these cell types is probably low in amount and readily released out of cells, since immunohistochemical localization of NGF in tissues has scarcely been reported except in the mouse submandibular gland. In the present study we have attempted the immunohistochemistry for NGF in the rat carotid body using several anti- 

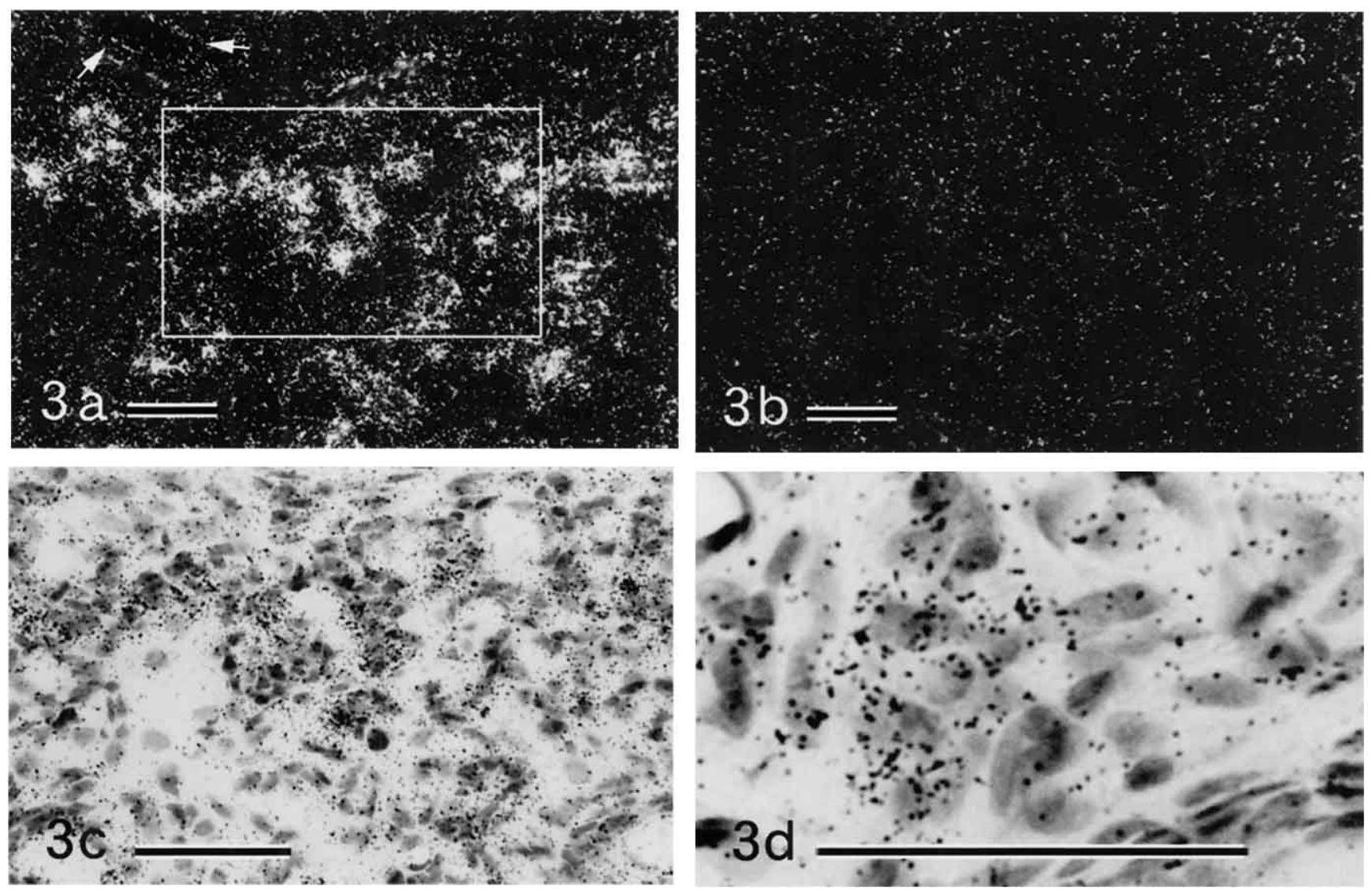

Fig. 3. Dark- (a, b) and bright-field (c, d) autoradiograms showing in situ hybridization of carotid body with ${ }^{35}$ S-labeled antisense- (a, c, d) and sense-NGF probes (b). (c) is a magnification of the inset in $(\mathbf{a})$. (a, c) Silver grains representing NGF-mRNA signal are accumulated in scattered cell groups. On the wall of the carotid artery (arrows), no specific accumulation of silver grains is detected. (d) Silver grains are accumulated in chief cells and sustentacular cells identified by their round nucleus and rich cytoplasm, but it is not clear if the grains are also present in sustentacular cells. (b) No specific signal is detected in the section hybridized with the sense probe. Bar=50 $\mu \mathrm{m}$.

NGF antibodies of different sources, but have failed to detect significant immunoreactivity. Taking into account the fact that some neurons exhibit high levels of NGF by internalization and retrograde transport despite the absence of NGF synthesis [9, 14], in situ hybridization detection of NGF mRNA adopted in the present study deserves to be the primary choice for demonstrating cellular production of NGF.

In the sympathetic ganglia, the postganglionic neurons are known to express TrkA but not NGF [39]. In the adrenal medulla, reverse transcriptase-polymerase chain reaction demonstrated that NGF mRNA is weakly expressed in chromaffin cells during $0-16$ days postpartum but is no longer detectable in adult mice, whereas trkA mRNA is detected in chromaffin cells from the embryonic days and become further abundant in adulthood [36]. The present results demonstrate that the carotid body chief cell is unique among the cells of sympathoadrenal lineage in that it express both NGF and its receptor, TrkA.

Visceral afferent neurons play a key role in regulating autonomic homeostasis. The cell bodies of visceral afferent neurons are mostly located in the nodose ganglion of vagal nerve and the petrosal ganglion of glossopharyngeal nerve, although a subset of the neurons in dorsal root ganglia also innervates visceral targets [41]. The carotid body is projected primarily by the visceral afferent neurons of petrosal ganglion [18]. In addition, the carotid body is projected by the sympathetic efferent neurons of the superior cervical ganglion [28]. The present result demonstrates bundles of TrkA-immunoreactive unmyelinated axons in the carotid body. Whether these axons belong to the afferent or efferent neurons is unknown and should be clarified by further study using such experimental procedures as removal of ganglia and transsection of nerve fibers. Considering the known effects of target-derived NGF on the growth and survival of sympathetic nerves, it seems reasonable to assume that NGF produced by carotid body chief cells and/or sustentacular cells exerts a trophic effect on the sympathetic efferent neurons projecting the carotid body.

In the brain, the neurons of the hippocampus express NGF [4] and the neurons of forebrain projecting the hippocampus express trkA [15], suggesting that NGF can also exert a trophic effect through neuron-to-neuron interactions. Furthermore, co-expression of NGF and trkA within the 
same neuron has been reported for subsets of neurons within the developing forebrain [25]. Similarly, the present result showing co-expression of NGF and TrkA in chief cells of the adult rat carotid body suggests paracrine/autocrine roles of NGF in this organ. The carotid body chief cells, having a neural crest origin, may exert trophic and/or regulatory functions through NGF not only on the projecting neurons but also on the neighboring chief cells.

\section{Acknowledgments}

We thank S. Yamazaki for his photographic work.

\section{References}

1. Aloe, L. and Levi-Montalcini, R. (1980) Comparative studies on the effects elicited by pre- and postnatal injections of anti-NGF, guanethidine, and 6-hydroxydopamine in chromaffin and ganglion cells of adrenal medulla and carotid body in infant rats. Adv. Biochem. Psychopharmacol. 25; 221-226.

2. Amano, O. and Iseki, S. (2001) Antisense oligonucleotide targeting cAMP response element-binding protein inhibits growth of rat submandibular gland in vitro. Acta Histochem. Cytochem. 34; 111-117.

3. Anderson, D. J. (1993) Cell fate determination in the peripheral nervous system: the sympathoadrenal progenitor. J. Neurobiol. $24 ; 185-198$

4. Ayer-LeLievre, C., Olson, L., Ebendal, T., Seiger, A. and Persson, H. (1988) Expression of the $\beta$-nerve growth factor gene in hippocampal neurons. Science 240; 1339-1341.

5. Baker, P. A. and Shooter, E. M. (1994) Disruption of NGF binding to the low affinity neurotrophin receptor p75LNTR reduces NGF binding to TrkA on PC12 cells. Neuron 13; 203-215.

6. Bandtlow, C. E., Heumann, R., Schwab, M. E. and Thoenen, H. (1987) Cellular localization of nerve growth factor synthesis by in situ hybridization. EMBO J. 6; 891-899.

7. Bhattacharya, A., Watson, F. L., Bradlee, T. A., Pomeroy, S. L., Stiles, C. D. and Segal, R. A. (1997) Trk receptors function as rapid retrograde signal carriers in the adult nervous system. J. Neurosci. 15; 7007-7016.

8. Bibel, M. and Barde, Y.-A. (2000) Neurotrophins: key regulators of cell fate and cell shape in the vertebrate nervous system. Genes Dev. 14; 2919-2937.

9. Claude, P., Hawrot, E., Dunis, D. A. and Campenot, R. B. (1982) Binding, internalization, and retrograde transport of 125I-nerve growth factor in cultured rat sympathetic neurons. J. Neurosci. 2; 431-442.

10. Claude, P., Parada, I. M., Gordon, K. A., D'Amore, P. A. and Wagner, J. A. (1988) Acidic fibroblast growth factor stimulates adrenal chromaffin cells to proliferate and to extend neurites, but is not a long-term survival factor. Neuron 1; 783-790.

11. Eyzaguirre, C., Fitzgerald, R. S., Lahiri, S. and Zapat, A. P. (1983) Arterial chemoreceptors. In "Handbook of Physiology, The Cardiovascular System. section 3 Vol II.", ed. by J. T. Shepperd and F. Abboud, Am Physiol Soc., Bethesda MD, pp. 557-621.

12. Fishman, M. C. and Schaffner, A. E. (1984) Carotid body cell culture and selective growth of glomus cells. Am. J. Physiol. 246; C106-C113.

13. Gonzalez, C., Almaraz, L., Obeso, A. and Rigual, R. (1994) Carotid body chemoreceptors; from natural stimuli to sensory discharges. Physiol. Rev. 74; 829-898.

14. Heumann, R., Korsching, S., Scott, J. and Thoenen, H. (1984) Relationship between levels of nerve growth factor (NGF) and its messenger RNA in sympathetic ganglia and peripheral target tissues. EMBO J. 3; 3183-3189.

15. Holtzman, D. M., Li, Y., Parada, L. F., Kinsman, S., Chen, C. K., Valletta, J. S., Zhou, J., Long, J. B. and Mobley, W. C. (1992) p140 ${ }^{\text {trk }}$ mRNA marks NGF-responsive forebrain neurons: evidence that trk gene expression in induced by NGF. Neuron 9; $465-478$

16. Huang, E. J. and Reichardt, L. F. (2003) Trk receptors: roles in neuronal signal transduction. Annu. Rev. Biochem. 72; 609-642.

17. Jackson, A. and Nurse, C. A. (1995) Plasticity in cultured carotid body chemoreceptors: environmental modulation of GAP-43 and neurofilament. J Neurobiol. 26; 485-496.

18. Katz, D. M. and Black, I. B. (1986) Expression and regulation of catecholaminergic traits in primary sensory neurons: relationship to target innervation in vivo. J. Neurosci. 6; 983-989.

19. Klees, L. J. and Parada, L. F. (1999) Trks: signal transduction and intracellular pathways. Micros. Res. Tech. 45; 210-216.

20. Kondo, H., Iwanaga, T. and Nakajima, T. (1982) Immunocytochemical study on the localization of neuron-specific enolase and S-100 protein in the carotid body of rats. Cell Tissue Res. 227; 291-295.

21. Kondo, H. and Yamamoto, M. (1993) Multi-unit compartmentation of the carotid body chemoreceptor by perineurial cell sheaths: immunohistoshemistry and freeze-fracture study. In "Neurobiology and Cell Physiology of Chemoreception", ed. by P. G. Data, Plenum Press, New York, pp. 61-66.

22. Levi-Montalcini, R. (1987) The nerve growth factor 35 years later. Science 237; 1154-1162.

23. Martin-Zanca, D., Oskam, R., Mitra, G., Copeland, T. and Barbacid, M. (1989) Molecular and biochemical characterization of the human trk proto-oncogene. Mol. Cell Biol. 9; 24-33.

24. McDonald, D. M. and Mitchell, R. A. (1981) The neural pathway involved in "efferent inhibition" of chemoreceptors in the cat carotid body. J. Comp. Neurol. 201; 457-476.

25. Miranda, R. C., Sohrabji, F. and Toran-Allerand, C. D. (1993) Neuronal colocalization of mRNAs for neurotrophins and their receptors in the developing central nervous system suggests a potential for autocrine interactions. Proc. Natl. Acad. Sci. U S A 90; 6439-6443.

26. Müller, T. H. and Unsicker, K. (1986) Nerve growth factor and dexamethasone modulate synthesis and storage of catecholamines in cultured rat adrenal medullary cells: dependence on postnatal age. J. Neurochem. 46; 516-514.

27. Nurse, C. A. (1987) Localization of acetylcholinesterase in dissociated cell cultures of the carotid body of the rat. Cell Tissue Res. 250; 21-27.

28. O'Regan, R. G. and Majcherczyk, S. (1983) Control of peripheral chemoreceptors by efferent nerves. In "Physiology of the Peripheral Arterial Chemoreceptors", ed. by H. Acker and R. G. O'Regan, Elsevier, Amsterdam, pp. 257-298.

29. Patterson, P. H. (1990) Control of cell fate in a vertebrate neurogenic lineage. Cell 62; 1035-1038.

30. Pearse, A. G. E., Polak, J. M., Rost, F. W. D., Fontaine, J., LeLievre, C. and LeDouarin, N. (1973) Demonstration of the neural crest origin of type 1 (APUD) cells in avian carotid body, using a cytochemical marker system. Histochemie 34; 191-203.

31. Rydel, R. E. and Greene, L. A. (1987) Acidic and basic fibroblast growth factors promote stable neurite outgrowth and neuronal differentiation in culture of PC12 cells. J. Neurosci. 7; 36393653.

32. Shelton, D. L. and Reichardt, L. F. (1984) Expression of the $\beta$ nerve growth factor gene correlates with the density of sympathetic innervation in effector organs. Proc. Natl. Acad. Sci. US A 81; 7951-7955.

33. Sofroniew, M. V., Howe, C. L. and Mobley, W. C. (2001) Nerve growth factor signaling, neuroprotection, and neural repair. Ann. Rev. Neurosci. 24; 1217-1281. 
34. Stea, A., Jackson, A. and Nurse, C. A. (1992) Hypoxia and N6, O2'-dibutyryladenosine 3',5'-cyclic monophosphate, but not nerve growth factor, induce $\mathrm{Na}+$ channels and hypertrophy in chromaffin-like arterial chemoreceptors. Proc. Natl. Acad. Sci. U S A 89; 9469-9473.

35. Stemple, D. L., Mahanthappa, N. K. and Anderson, D. J. (1988) Basic FGF induces neuronal differentiation, cell division, and NGF dependence in chromaffin cells: a sequence of events in sympathetic development. Neuron 1; 517-525.

36. Suter-Crazzolara, C., Lachmund, A., Arab, S. F. and Unsicker, K. (1996) Expression of neurotrophins and their receptors in the developing and adult rat adrenal gland. Mol. Brain Res. 43; 351355.

37. Vega, J. A., Vazquez, E., Naves, F. J., Del Valle, M. E., Calzada, B. and Represa, J. J. (1994) Immunohistochemical localization of the high-affinity NGF receptor (gp-140-trkA) in the adult human dorsal root and sympathetic ganglia and in the nerves and sensory corpuscles supplying digital skin. Anat. Rec. 240; 579-588.

38. Wakayama, T. and Iseki, S. (1999) Specific expression of the
mRNA for $25 \mathrm{kDA}$ heat-shock protein in the spermatocytes of mouse seminiferous tubules. Anat. Embryol. 199; 419-425.

39. Wetmore, C. and Olson, L. (1995) Neuronal and nonneuronal expression of neurotrophins and their receptors in sensory and sympathetic ganglia suggest new intercellular trophic interactions. J. Comp. Neurol. 353; 143-159.

40. Whittemore, S. R., Friedman, P. L., Larhammar, D., Persson, H., Gonzalez-Carvajal, M. and Holets, V. R. (1988) Rat $\beta$-nerve growth factor sequence and site of synthesis in the adult hippocampus. J. Neurosci. Res. 20; 403-410.

41. Willis, W. D. and Coggeshall, R. E. (1991) Sensory Mechanisms of the Spinal Cord, Plenum Press, New York.

42. Yamamoto, M., Kondo, H. and Iseki, S. (1992) Nerve growth factor receptor (NGFR)-like immunoreactivity in the perineurial cell in normal and sectioned peripheral nerves of rats. Anat. Rec. $233 ; 301-308$

43. Zhong, H. and Nurse, C. (1995) Basic fibroblast growth factor regulates ionic currents and excitability of fetal rat carotid body chemoreceptors. Neurosci. Lett. 202; 41-44. 